\title{
Pasang-Surut Komitmen Kebangsaan
}

\author{
Yudi Latif \\ Mantan Wakil Rektor Universitas Paramadina, Pengasuh Pesantren Ilmu Kema- nusiaan dan \\ Kenegaraan (PeKiK-Indonesia) \& Dewan Ahli Nurcholish Madjid Society
}

\begin{abstract}
Our national commitment can be seen through three phases, namely in the early days of independence, in the New Order era, and in the Reform Era. Our national commitment at the beginning of the independen-ce is scratched as negative-defensive nationalism force, when it was faced with a common enemy from outside (colonization). Our national commit- ment in the New Order era is marked by making economy as the comman- der in terms of growth, stability and centralization of power, bringing a variety of inequality. The most striking, there is lack of harmony between the national and statehood character. National multicultural character of Indonesia was denied by the centralized nature of waking state. Imbalance between central and local government with denial of political, social, eco- nomic and cultural rights of local communities. Meanwhile, the national commitment in the Reformation Era is characterized by openness and free-dom of public space that brings euphoria for the expression of marginalized identities. Efforts to bring diversity of expression "plural monoculturalism" into the situation of "multi-culturalism"- with willingness of being differen-ce (pluralism) and willingness of being united (cosmopolitanism) - requires a new solidarity framework, which is based on the premises of political na- tionalism based on rationality, volunteerism and shared prosperity.
\end{abstract}

Kata Kunci: nasionalisme; kebangsaan; pluralism; monokulturalisme

\section{Pendahuluan}

Penanda penting yang mewarnai Kerapatan Besar Pemuda Indonesia (KBPI) II, 28 Oktober 1928, adalah penggunaan bahasa Melayu (Indonesia) sebagai bahasa utama Kongres. Pilihan ini merupakan lompatan radikal dari KBPI I, dua tahun sebelumnya, yang menggunakan bahasa Belanda sebagai bahasa utama. Suatu trajektori baru dalam kesadaran nasional, ditandai oleh pena- rikan batas antara dunia penjajah dan yang terjajah dalam "universum sim- bolik"sebagai rumah kehidupan (the house of being) ${ }^{1}$.

Tetapi pemancangan tanda baru ini bukanlah perkara mudah. Bagi para pe- muda-pelajar yang terdidik dalam persekolahan dan komunitas epistemik bergaya Eropa, penggunaan bahasa Indonesia membawa kesulitan yang se- rius: menimbulkan kegagapan bagi pembicara dan kebingungan bagi pen- dengar.

Pengamat resmi dari Belanda, Van der Plas, melaporkan bahwa Soegondo Djojopoespito sebagai pemimpin Kongres tak mampu menunaikan tugasnya secara baik:

"Pemimpin kongres, pelajar Soegondo, tidak dapat memenuhi tugasnya dan kekurangan otoritas. Ia mencoba untuk berbicara bahasa Indonesia, tetapi tidak mampu membuktikan dirinya mampu melakukannya dengan baik." (Foulcher, 2008: 17)

\footnotetext{
${ }^{1}$ Sejak awal 1920-an, kerinduan akan pemisahan simbolis dengan bahasa kolonial telah bergema di lingkungan aktivis Perhimpunan Indonesia di Belanda, seperti tercer- min dalam pernyataan Sunarjo (seorang mahasiswa hukum di Leiden), "Saya merasa jijik dengan apa yang telah diperbuat oleh Belanda dan saya berniat segera setelah pu- lang ke Tanah Air akan mencari guru yang bisa membantu memperbaiki bahasa Melayu dan Jawa saya yang sangat terabaikan, karena keduanya dalam kondisi yang sangat menyedihkan.”.
} 


\section{Yudi Latif, Pasang-Surut Komitmen Kebangsaan}

\section{DOI: -}

http://www.konfrontasi.net/index.php/konfrontasi2

Dilaporkan pula, ada penolakan secara diam-diam dari beberapa peserta ter- hadap penggunaan bahasa Indonesia. Sedang beberapa yang lain tidaklah menolak, namun tak mampu menggunakannya; hingga akhirnya terpaksa menggunakan bahasa Belanda ${ }^{2}$. Salah seorang dalam kategori terakhir ada- lah Sitti Soendari, perwakilan dari Poetri Indonesia.

Tetapi komitmen kebangsaan membuat hal yang sulit membangkitkan tekad untuk menaklukkannya. Hanya selang dua bulan sejak peristiwa itu, Sitti Soendari secara heroik sanggup berpidato dalam bahasa Indonesia pada Kongres Perempuan Indonesia, 22-25 Desember 1928. Ia memulai pidato- nya dengan melakukan disklaimer:

"Sebeloem kami memoelai membitjarakan ini, patoetlah rasanja kalau kami terangkan lebih dahoeloe, mengapa kami tidak memakai bahasa Belanda atau bahasa Djawa. Boekan sekali-kali karena kami hendak me- rendahkan-rendahkan bahasa ini, atau mengoerangngoerangkan harga- nja. Itoe sekali-kali tidak. Tetapi barang siapa di antara toean jang mengoendjoengi kerapatan pemoeda di kota Djacatra (Betawi), jang diadakan beberapa boelan jang laloe atau setelah membatja poetoesan keraptan jang terseboet, tentoe masih mengingat akan hasilnja, jaitu hendak berbangsa jang satoe, bangsa Indonesia, hendak bertoempah da- rah jang satoe, tanah Indonesia, dan hendak mendjoendjoeng bahasa persatoean, bahasa Indonesia. Oleh karena jang terseboet inilah maka ka- mi sebagai poetri Indonesia jang lahir dipoelau Djawa jang indah ini be- rani memakai bahasa Indonesia dimoeka ra'jat kita ini. Boekankah kera- patan kita kerapatan Indonesia, ditimboelakan oleh poetri Indonesia dan dioentoekkan bagi seloeroeh kaoem istri dan poetri Indonesia, beserta ta- nah toempah darah dan bangsanja.,"3

Perubahan dahsyat dalam tempo cepat dari keberanian seorang Sitti Soen- dari menggunakan bahasa Indonesia, dengan melepaskan diri dari bahasa ibunya (Jawa) dan bahasa keduanya - dan juga bahasa intelektualnya (Be- landa), merupakan simbol dari kuatnya komitmen kebangsaan baru.

Komitmen menggunakan bahasa baru ini menandai transformasi dari "nasi- onalisme kultural" (cultural nationalism) menuju "nasionalisme politikal" (political nationalism). ${ }^{4}$ Gerakan-gerakan kebangkitan yang semula ter- kungkung dalam komunitas-komunitas berbasis etno-religius yang bersifat lokal dan fragmentaris, ${ }^{5}$ mulai mempertautkan diri ke dalam komunitas po- litik impian yang bersifat lintas-kultural, bernama "Indonesia".

Pada titik ini, nasionalisme politikal tumbuh melalui proses "sekularisasi", dalam bentuk demistifikasi ikatan warga dengan simbol-simbol primor- dialnya. Seturut dengan itu, fantasi inkorporasi baru dihidupkan berdasar- kan konsepsi kewargaan yang bersifat teritorial (territorial conception of citizenship), yang menjalin solidaritas atas dasar kesamaan tumpah darah- sama-

\footnotetext{
${ }^{2}$ Salah seorang peserta meminta maaf karena menggunakan bahasa Belanda dan menyatakan penyesalan "bahwa ia sendiri sebagai anak Indonesia tidak bisa berkata dalam bahasa sendiri". Ini merupakan pertanda kesadaran baru, karena hingga tahun 1928, penggunaan bahasa Belanda dalam konteks nasional tidak pernah menjadi sebab sebuah permintaan maaf (Foulcher, 2008: 19).

${ }^{3}$ Lihat proceeding Kongres Perempuan Indonesia dalam Blackburn (2008: 185).

${ }^{4}$ Cultural nationalism adalah suatu konsepsi kebangsaan yang memandang bahwa humanitas secara inheren diorganisasikan ke dalam komunitas historis, yang masing- masing diwarnai oleh kekuatan uniknya tersendiri, yang diekspresikan melalui kekhasan budaya, berbasiskan pada kampung halaman alamiah (naturan homelands) dengan tata- pemerintahannya yang khas. Political nationalism adalah suatu konsepsi kebangsaan atas dasar visi voluntaris pencerahan yang memandang bangsa sebagai komunitas politik dari kehendak bersama (political community of will) yang dibangun atas pembuatan kepu- tusan yang bersifat rasional dari warga negara yang sederajat dan diekspresikan melalui mekanisme negara teritorial. Lihat Hutchinson (2005: 45-46).

${ }^{5}$ Untuk menyebut beberapa contoh dari gerakan-gerakan proto-nasionalis ini, Budi Utomo (1908), Sarekat Islam (1912), Jong Java (1915), Jong Sumatranen Bond (1917), Jong Celebes (1918), Jong Minahasa (1918), Sekar Roekoen (1919), Jong Bataks Bond (1925), dan Jong Islamieten Bond (1925).
} 
Konfrontasi: Jurnal Kultur, Ekonomi dan Perubahan Sosial, 1 (1) Januari 2014, 50-59

P-ISSN: $1410-881 X$ (Print)

\section{Yudi Latif, Pasang-Surut Komitmen Kebangsaan}

DOI: -

http://www.konfrontasi.net/index.php/konfrontasi2

sama anak negeri terjajah.

Demikianlah, lewat Sumpah Pemuda, kaum muda dengan kesadaran baru menerobos kelembaman solidaritas etno-religius melalui "penemuan" politik (the invention of politics). Bukan saja, hingga awal abad KE-20, bahasa Mela- yu-Indonesia tidak memiliki kata yang spesifik untuk 'politik'; tetapi yang le- bih penting, pemuda-pelajar pada akhir 1920-AN mulai merumuskan kon-sepsi baru ideologi politik perjuangan. Perjuangan politik untuk menjel- makan suatu nation of citizens yang dapat menyatukan pelbagai keragaman posisi, determinasi dan aliran kultural ke dalam suatu blok nasional (historical bloc). ${ }^{6}$

Komitmen kebangsaan kaum muda ini terbukti tidaklah bertepuk sebelah tangan. Menyusul peristiwa Sumpah Pemuda, berbagai organisasi perge- rakan dari berbagai latar etnis-keagamaan mulai mengintegrasikan diri ke dalam keindonesian dengan membubuhkan kata "Indonesia" dalam nama- nya. Sarekat Islam bermetamorfosis menjadi Partai Sjarikat Islam Indonesia (PSII) pada 1929. Budi Utomo bertransformasi menjadi Partai Indonesia Raya (Parindra) pada 1935. Komunitas Protestan mulai mendirikan Parta Kaum Masehi Indonesia (PKMI) pada 1930, disusul kemunculan Federasi Perkumpulan Kristen Indonesia (FPKI) pada 1939. Komunitas Katolik men- dirikan Persatuan Politik Katolik Indonesia (PPKI) pada 1938. ${ }^{7}$ Komunitas agama-agama lain seperti Hindu-Budha mempertautkan diri dengan ke- Indonesiaan melalui keterlibatan anggota-anggotanya dalam berbagai perge- rakan dan partai politik yang ada.

Pengikatan bersama komitmen kebangsaan dari berbagai identitas kolektif (etnis, agama, kelas dan jender) ini pada akhirnya berhasil mengantarkan bangsa Indonesia ke pintu gerbang kemerdekaannya. Sejarah membuktikan, nasionalisme politik Indonesia cukup mampu merajut kepentingan masya- rakat plural yang sulit menemukan kehendak bersama.

Komitmen Kebangsaan Awal Kemerdekaan

Tetapi, keampuhan nasionalisme politikal ini baru teruji sebagai kekuatan nasionalisme negatif-defensif, ketika dihadapkan pada keburukan musuh bersama dari luar (penjajahan). Padahal, dengan berlalunya kolonial, proyek kebangsaan Indonesia yang berlandaskan pada penemuan "batas" dan "lawan" dengan kolonial itu tak bisa lagi dipertahankan.

Nasionalisme politikal dituntut merealisasikan cita-cita kemerdekaan dan tujuan nasionalnya. Untuk mempertahankan kehendak bersama dan hori- zontal comradeship, nasionalisme harus memecahkan masalah-masalah konkrit, yang sumber-sumber masalahnya tidak bisa melulu dialamatkan kepada kejahatan musuh dari luar.

Ketika nasionalisme politikal gagal merealisasikan janji-janjinya, maka ana- sir-anasir nasionalisme kultural akan menguat kembali. Hendaklah disadari pula bahwa kesadaran (rasionalitas) nasionalisme politik tidaklah bero- perasi dalam suatu tabula rasa, melainkan tumbuh di atas pola-pola keti- daksadaran kolektif terdahulu, yang disebut Carl Gustav Jung sebagai arche- types. Yakni berbagai bentuk sumberdaya etno-komunal seperti imaji, sim- bol, mitos dan ritus etno-religius yang diwariskan ribuan tahun lamanya.

Berbeda dengan keyakinan utopian kaum modernis yang percaya bahwa sekali negara bangsa terbentuk, negara nasional akan beroperasi sebagai satu kesatuan sosial yang koheren,

\footnotetext{
${ }^{6}$ Politik dalam kesadaran kaum uda ini jauh dari bahasa teori 'pilihan rasional' bahwa rationalitas kepentingan individual harus dibayar oleh irasionalitas kehidupan kolektif. Politik dalam konsepsi mereka merupakan usaha resolusi atas problem-prob- lem kolektif dengan pemenuhan kebajikan kolektif. Mirip dengan pemahaman Aristotelian, politik dipandang sebagai seni mulia untuk meraih harapan dan meme-lihara kemaslahatan umum, terutama kepentingan kaum terjajah, dengan jalan mensubor- dinasikan kepentingan-kepentingan partikular pada kepentingan (kaum terjajah) seca-ra keseluruhan.

${ }^{7}$ Merupakan metamorfosis dari Pakempalan Politik Katolik Djawi (PPKD) yang ber- diri pada 1923
} 
Konfrontasi: Jurnal Kultur, Ekonomi dan Perubahan Sosial, 1 (1) Januari 2014, 50-59

P-ISSN: $1410-881 X$ (Print)

\section{Yudi Latif, Pasang-Surut Komitmen Kebangsaan}

DOI: -

http://www.konfrontasi.net/index.php/konfrontasi2

yang pembangunannya akan diarahkan dari pusat politik. Kenyataannya selalu ada batas sekularisasi, rasionalisasi dan kemampuan negara-nasional untuk memberikan makna dan memper- tahankan dominasi terhadap penduduknya.

Bahkan Perancis, sebagai contoh terbaik dari negara sipik (civic state), ber- basis konsepsi nasion yang bersifat rasional dan voluntaris pada kenya- taannya tak bisa sepenuhnya menghabisi simbol-simbol etno-komunal ter- dahulu. Universalisme dari Revolusi Perancis berpijak pada konsepsi etnis terdahulu bahwa Perancis memiliki misi khusus terhadap Eropa, sebagai pewaris peradaban Romawi dan Caroling dan sebagai penjaga terpilih dari Kekristenan Katolik Eropa (Armstrong, 1982: bab 5). Lebih dari itu, meski- pun Republik Perancis mengembankan negara sekular yang tersentralisasi secara kuat, dalam kenyataannya tak pernah mampu untuk mencerabut bu- daya Katolik yang hidup di tengah-tengah warganya, yang mempertahan- kan sumber-sumber tandingan terhadap republikan yang berlanjut hingga saat ini (Hutchinson, 2005: 38).

Perlu juga diingat bahwa perubahan-perubahan alam yang tak terduga-pe- nyakit, kelaparan, kerusakan ekologis, dan pergeseran pola fertilitas-memi- liki dampak disruptif dalam relasi antarpenduduk, yang pada gilirannya juga mempengaruhi keampuhan nasionalisme politik. Ketidakmampuan peme- rintah Britania untuk mengatasi kelaparan hebat di Irlandia pada perte- ngahan abad KE-19 menyebabkan alienasi secara permanen orang-orang Ka- tolik Irlandia dari pertautannya dengan Britania.

Di dalam ketidakpuasannya terhadap kinerja pemerintahan pusat, dan di dalam kompetisi antar kelompok etno-komunal, kerapkali usaha untuk ber- tahan hidup diperjuangkan dengan kembali berpaling ke sumber-sumber moral dan politik dari nasionalisme kultural. Dalam pada itu, ketidakmam- puan pemerintahan dan elit politik untuk membuat politik bermakna bagi warganya, mendorong mereka berpaling ke simbol dan sentimen etno-ko- munal dalam rangka memobilisasi dukungan massa.

Situasi inilah yang segera Indonesia alami setelah proklamasi kemerdekaan. Ketika historical bloc yang dibangun atas dasar nasionalisme negatif-defen- sif kehilangan kontekstualitasnya, komunitas politik kembali ke "normali- tasnya": pluralitas.

Nation building dalam masyarakat plural terbukti merupakan masalah yang pelik. Tidaklah berarti tidak mungkin. Seperti kata Arend Lijphart (1977), adalah mungkin untuk mengembangkan nasionalisme dan pemerintahan demokratis yang stabil dalam masyarakat plural, sejauh elit politiknya mau bekerja sama. Tetapi kesediaan bekerjasama ini hanya bisa dikembangkan jika terdapat kerangka solidaritas baru, berupa kehadiran nasionalisme sipik (civic nationalisme). Dalam kenyataannya, nasionalisme sipik yang berbasis kewargaan inklusif (inclusive citizenship) dan dan kebajikan sipil (the virtue of civility) ini belumlah berkembang baik di Indonesia pasca-kolonial.

Dalam hal ini, penilian Edward Shils tentang kecenderungan intelektual di negara-negara berkembang mengandung kadar kebenarannya:

Meskipun intelektual di negara-negara terbelakang telah memiliki ide ke- bangsaan di dalam negerinya sendiri, mereka toh belum berhasil mencip- takan sebuah bangsa. Malahan, mereka menjadi korban dari idenya sendiri, ketika nasionalisme tidak mengarah pada perwujudan kewargaan (citizenship). Keanggotaan dalam suatu bangsa memerlukan rasa pertautan dengan orang-orang lain yang sama-sama membentuk bangsa. Hal itu juga memerlukan rasa kemitraan, dan kesediaan untuk berbagi substansi bersama, melampaui kepentingan kelompok, melunakkan dan menyerahkannya secara toleran kepada tertib sipil, menganggap hal itu sebagai kurang signifikan ketimbang kepentingan komunitas bangsa se- cara keseluruhan. Dalam kehidupan politik, watak serupa itu membentuk apa yang disebut sebagai kebajikan 


\section{Yudi Latif, Pasang-Surut Komitmen Kebangsaan}

\section{DOI: -}

http://www.konfrontasi.net/index.php/konfrontasi2

sivilitas (the virtue of civility). Sayang sekali, kebajikan seperti itu bukan merupakan gambaran umum dari ka- um inteligensia-politik di negara-negara tersebut. Yang berkembang di sini adalah suatu kecenderungan padat politisasi (intense politicization) yang disertai oleh keyakinan bahwa hanya mereka yang memiliki kesa- maan prinsip dan posisilah yang dianggap sebagai anggota absah dari masyarakat politik (polity). Sedangkan mereka yang berbeda dikucilkan oleh curam hambaran yang terjal.

Inteligensia-politisi, yang diharapkan membimbing komunitas politik ke arah keadaban politik (political civility), pada kenyataannya malah menyu- burkan komunalisme. Sebagian karena tak memiliki landasan ekonomi yang kuat, kelompok-kelompok inteligensia-politisi saling bersaing untuk mengu- asai birokrasi dan ekonomi negara. Dan kehendak untuk mengontrol sum- bersumber daya itu membutuhkan justifikasi sosial. Dalam konteks inilah, kepentingan-kepentingan komunal menjadi dalih yang kuat. Solidaritas etno-komunal kemudian dipolitisasi dalam situasi-situasi konflik yang isu- isu utamanya sering kali adalah kepentingankepentingan ekonomi-kekuasa- an dari elit politik.

Dengan intensitas politisasi, elite settlement dalam 25 tahun pasca prok- lamasi sulit diupayakan. Konflik ideologis bersanding dengan ketegangan antara yang disebut Herbert Feith "solidarity makers" dan "administrators", yang tak pernah terpecahkan secara efektif. Sulit menemukan pemimpin yang berusaha mengaitkan tujuan jangka panjang dengan programprogram administratif jangka pendek, antara daya tarik ideologis dengan solusi atas problemproblem teknis (FeiTH,1962: 34). Intensitas politisasi dan konflik ideologis yang bersanding dengan snobisme elit politik di tingkat pusat membuat state building terabaikan, yang pada gilirannya menelantarkan pembangunan ekonomi dan kesejahteraan sosial.

Sejak 1952, Soekarno telah mengingatkan tentang lima macam krisis yang bisa mematikan kehidupan politik nasional. Pertama, krisis politik, yang membuat banyak orang tidak percaya lagi kepada demokrasi; kedua, krisis alat-alat kekuasaan Negara; ketiga, krisis cara berfikir dan cara meninjau; keempat, krisis moral; kelima, krisis Gejag (kewibawaan otoritas).

Dengan berbagai macam krisis yang melanda pusat politik sebagai pusat te- ladan, kekecewaan, ketidakpercayaan, dan kekacauan muncul di daerah- daerah pinggiran. Komitmen kebangsaan mengalami ujian berat dari bang- kitnya kembali kesadaran nasionalisme kultural dalam bentuk pemberon- takan kedaerahan dan keagamaan.

\section{Komitmen Kebangsaan Era Orde Baru}

Koreksi Orde Baru atas hal ini dengan menjadikan ekonomi sebagai pang- lima dalam kerangka pertumbuhan, stabilitas dan sentralisasi kekuasaan membawa aneka ketimpangan. Yang paling mencolok, terdapat ketidak- selarasan antara watak kenegaraan dan watak kebangsaan. Watak multi- kultural kebangsaan Indonesia dinafikan oleh watak sentralistik bangun kenegaraan. Ketimpangan antara pusat dan daerah terjadi dengan penging- karan terhadap hak-hak politik, sosial, ekonomi dan budaya masyarakat lokal.

Karena penguasaan kapital oleh segelintir pihak di titik pusat, persebaran kapital yang melicinkan mobilitas vertikal dan horizontal terhambat. Sifat insular negri kepulauan yang menyulitkan kontak dalam intensitas tinggi tak menemukan jembatan katalisnya. ${ }^{8}$

\footnotetext{
${ }^{8}$ Situasi ini telah lama dirisaukan Bung Hatta. Membandingkan pengalaman Italia (negri agraris) dan Inggris (negri Industri) dalam mengembangkan persatuan nasional, ia temukan bahwa rasa persatuan nasional di Italia lebih rapuh. Menurut Bung Hatta, sifat petani yang terikat hatinya pada tanah menyulitkan mobilitas dan intensitas hubunganya dengan kalangan yang lebih luas. Rasa persatuan nasional secara umum lebih kuat di negri industri tempat rakyatnya yang memburuh terlepas dari ikatan tanah dan disusun bersatu oleh pabrik dan disiplin kerja. Di sini,
} 


\section{Yudi Latif, Pasang-Surut Komitmen Kebangsaan}

\section{DOI: -}

http://www.konfrontasi.net/index.php/konfrontasi2

Dalam ketersendatan lau lintas pergaulan, masyarakat lebih banyak terkung- kung dalam kepompong komunalisme. Dalam situasi demikian, pembica- raan di seputar SARA (suku, agama, ras dan antargolongan) ditabukan ber- sanding dengan pemaksaan kebijakan asimilasi, yang melahirkan fenomena "dekulturisasi" bagi etnis tertentu, seperti Tionghoa. Akibatnya, Indonesia sebagai masyarakat plural terkunci dalam situasi "plural monokultralisme"; terdiri dari banyak etnis yang hidup dalam kepompong budayanya masing- masing, dengan keterhambatan proses penyerbukan silang budaya secara alamiah.

Pengikatan komitmen kebangsaan dari jaringan komunalisme ini sekedar bertumpu pada solidaritas emosional yang tersisa dari warisan kesamaan sejarah, bahasa, dan budayakeagamaan. Tanpa solidaritas fungsional yang lahir karena persamaan kepentingan dan pemenuhan kesejahteraan bersa- ma, komitmen kebangsaan mudah retak oleh gerak sentrifugal dari ingatan pedih ketidakadilan dan keterkucilan.

Dengan proses belajar kolektif lebih banyak dimediasikan oleh paguyuban yang tertutup, ketimbang oleh asosiasi yang terbuka, universum simbolik yang menyediakan kerangka interpretasi sosial lebih membiaskan gramatika komunalisme. Akibatnya, kekecewaan sosialekonomi sering disublimasikan ke dalam sentimen etno-religius. Ketika nasionalisme politik tak banyak memberi makna bagi kehidupan rakyat, terutama di daerah, gramatika ko- munalisme akan memudahkan rakyat berpaling ke nasionalisme kultural se- bagai cara menemukan makna dan harapan.

\section{Komitmen Kebangsaan Era Reformasi}

Keterbukaan dan kebebasan ruang publik Orde Reformasi membawa eforia bagi pengekspresian identitas-identitas yang termajinalkan. Usaha memba- wa ragam ekspresi "plural monokulturalisme" ini ke dalam situasi "multi- kulturalisme"-dengan kesediaan berbeda (pluralisme) dan kesediaan bersa- tu (kosmopolitanisme)-menuntut adanya kerangka solidaritas baru.

Kerangka solidaritas baru ini harus bertumpu pada premis-premis nasional- isme politikal yang berbasis pada rasionalitas, kesukarelaan dan persemak- muran bersama. Pada akhirnya, seperti diisyaratkan John Ralws, sumber persatuan dan komitmen kebangsaan dari negeri multikultural adalah "kon- sepsi keadilan bersama" (a share conception of justice). "Meskipun suatu masyarakat bangsa terbagi dan pluralistik...kesepakatan publik atas persoalan-persoalan keadilan sosial dan politik mendukung persaudaraan sipik dan menjamin ikatanikatan asosiasi" (Raws, 1980: 540).

Setelah sepuluh tahun reformasi digulirkan, Indonesia telah menghasilkan banyak perubahan dari segi prosedural, namun belum membawa kemajuan berarti secara substansial. Padahal, di benak kebanyakan rakyat yang telah lama mengalami penindasan, ketidakadilan dan kemiskinan, demokrasi me- lambangkan lebih dari sekadar penghapusan institusi-institusi politik yang represif dan penggantian pemimpin-pemimpin otoriter. Demokrasi merep- resentasikan kesempatan dan sumberdaya bagi perbaikan kualitas hidup serta bagi kehidupan sosial yang lebih adil dan manusiawi.

Seturut dengan cita-cita republikanisme demokratis, warga negara harus menikmati persamaan hak-hak ekonomi, sosial dan budaya agar kebebasan tidak mengarah pada penguasaan seseorang atau suatu golongan terhadap yang lain. Kebebasan tanpa keadilan hanya membuat tirani berganti wajah, dari wajah bengis militeristik menuju wajah lembut permainan prosedur.

mobilitas penduduk tidak dipaksakan, semisal lewat transmigrasi melainkan tumbuh secara suka rela mengikuti pergerakan kapital. 


\section{Yudi Latif, Pasang-Surut Komitmen Kebangsaan}

\section{DOI: -}

http://www.konfrontasi.net/index.php/konfrontasi2

Jika persoalan demokrasi kita adalah defisit keadilan, bukan kebebasan, ma- ka isu utamanya bukanlah pergantian elit dan prosedur politik, melainkan pada kapasitas transformatif dari kekuasaan. Bagaimana mengakhiri gerak sentripetal dari kekuasaan yang bersifat narsistik menuju gerak sentrifugal yang berorientasi pada kemaslahatan umum. Malangnya, pergeseran dari rezim otoritatian menuju demokrasi di Indonesia belum menyentuh aspek ini, sehingga upaya-upaya reformasi belum mampu mewujudkan "a share conception of justice".

Lemahnya perwujudan keadilan bersama melemahkan fondasi nasionalisme politik, dalam situasi ketika arus globalisasi kian menguat beriringan dengan gejala revivalisme etno-religius.

Pada ranah negara-bangsa, globalisasi menarik (pull away) sebagian dari kedaulatan negara-bangsa dan komunitas lokal untuk diserahkan ke otoritas (maya) global. Negara-bangsa menjadi dirasa terlalu kecil untuk menye- lesaikan berbagai masalah global seperti isu perdagangan bebas, terorisme, human trafficking, dan global warming. Saat yang sama, globalisasi juga menekan negara-bangsa ke bawah, menciptakan tekanan baru bagi otonomi lokal. Negara-bangsa menjadi dirasa terlalu besar untuk menyelesaikan renik-renik masalah di tingkat lokal.

Rongrongan terhadap otoritas negara ini terjadi ketika negara-bangsa Indo- nesia sedang bertransformasi menuju demokrasi, yang menghendaki pengu- atan otoritas negara guna merespon meluasnya tuntutan rakyat di dalam negeri. Tanpa pemulihan otoritas negara, transisi menuju demokrasi, seperti yang berlangsung di Indonesia saat ini, kerapkali hanyalah membuat pendu- lum sejarah berayun dari situasi otoriter menuju situasi tanpa otoritas.

Selain implikasi globalisasi, melemahnya otoritas negara ini terutama dise- babkan oleh berbagai krisis politik seperti yang pernah dikeluhkan Soekarno pada 1952. Bertahun-tahun pemerintahan demokratis diperjuangkan de- ngan keringat dan darah. Tetapi, ketika kesempatan itu diraih, politik tak berkhidmat bagi kepentingan orang banyak; aparatur Negara gagal mene- gakkan hukum dan ketertiban; politisi dan pejabat Negara miskin visi dan wawasan; perilaku politik tercerabut dari moralitas seperti terpisahnya air dengan minyak; adapun orang-orang yang menggenggam otoritas justru berlomba menghancurkan Gejag

Dalam situasi demikian, arus globalisasi yang bersanding dengan lokalisasi membawa paradoks global dalam kehidupan berbangsa. Tarikan global ke arah demokratisasi dan perlindungan hak-hak asasi memang menguat. Te- tapi oposisi dan antagonisme terhadap kecenderungan ini juga terjadi. Di se- luruh dunia, "politik identitas" (identity politics) yang mengukuhkan per- bedaan identitas kolektif — etnis, bahasa, agama, bahasa dan bangsa — mengalami gelombang pasang.

Karena setiap pencarian identitas memerlukan garis perbedaan dengan yang lain, maka politik identitas senantiasa merupakan politik penciptaan perbe- daan. Apa yang harus diwaspadai dari kecenderungan ini bukanlah dialek- tika yang tak terhindarkan dari identitas/perbedaan, melainkan suatu ke- mungkinan munculnya keyakinan atavistik bahwa identitas hanya bisa di- pertahankan dan diamankan dengan cara menghabisi perbedaan dan keber- lainan (otherness).

Tantangan berat terhadap nasionalisme politikal datang dari persenyawaan antara pengekspresian politik identitas yang bersifat trans-nasional dengan revivalisme sentimen kedaerahan. Komitmen kebangsaan bisa dilampaui oleh komitmen etno-komunal yang mendapatkan sumber-sumber moralitas dan idealitasnya dari gerakan-gerakan kebudayaan dan keagamaan trans- nasional.

Dalam situasi seperti itu, eksistensi Indonesia sebagai republik dituntut un- tuk berdiri kokoh di atas prinsip dasarnya. Ide sentral dari republikanisme menegaskan bahwa proses 
Konfrontasi: Jurnal Kultur, Ekonomi dan Perubahan Sosial, 1 (1) Januari 2014, 50-59

P-ISSN: 1410-881X (Print)

\section{Yudi Latif, Pasang-Surut Komitmen Kebangsaan}

\section{DOI: -}

http://www.konfrontasi.net/index.php/konfrontasi2

demokrasi bisa melayani sekaligus menjamin ter- jadinya integrasi sosial dari masyarakat yang makin mengalami ragam per- bedaan. Oleh karena itu, tantangan demokrasi ke depan adalah bagaimana mewujudkan pengakuan politik (political recognition) dan politik peng- akuan (politics of recognition) yang menjamin hak individu maupun kese- taraan hak dari aneka kelompok budaya, sehingga bisa hidup berdampingan secara damai dan produktif dalam suatu republik.

\section{Postcript}

Delapan puluh empat tahun setelah Sumpah Pemuda, Indonesia masih tetap merupakan proyek kebangsaan yang belum tuntas. Perjuangan Pemuda kerap kali lebih berhasil untuk "menjebol", tapi belum ampuh untuk "mem- bangun". Masalahnya, seperti kata Isiah Berlin, "Manusia tidaklah hidup sekadar untuk memerangi keburukan. Mereka hidup dengan tujuan yang positif, untuk menghadirkan kebaikan."

Untuk itu, perlu dihadirkan konsepsi nasionalisme yang lebih positif dan progresif. Nasionalisme yang tidak melulu bersandar pada apa yang bisa kita lawan, melainkan juga pada apa yang bisa kita tawarkan. Nasionalisme sejati haruslah berarti bukan sekadar mempertahankan melainkan juga memper- baiki keadaan negeri.

Para pendiri bangsa Indonesia sesungguhnya telah mewariskan kepada bangsa suatu kerangka dasar bagi pengembangan nasionalisme progresif. Fondasi dasar ini tertuang dalam "philosofische grondslag", bernama Panca- sila.

Sebagai philosofische grondslag, Pancasila merupakan kristalisasi dari nilai- nilai dan falsafah perjuangan bangsa. Gagasan Pancasila yang pertama kali dikemukakan secara publik pada 1 Juni 1945 bisa disejajarkan dengan doku- men-dokumen awal dari kelahiran Amerika Serikat, seperti misalnya Fede- ralist Paper yang mengiringi rentetan sejarah semenjak Declaration of Independence, atau pemikiran-pemikiran Montesquieu dan Rousseau bagi kelahiran Perancis sebagai Republik. Di sana ada suatu pergulatan yang terus berjalan, yang kemudian berelasi erat dengan peristiwa Sumpah Pemu- da 28 Oktober 1928, pergerakan Indonesia (termasuk Boedi Oetomo, Per- himpunan Indonesia, Indhische Partij, Sarekat Islam, Taman Siswa dan sebagainya) dan Proklamasi Kemerdekaan 17 Agustus 1945, berikut dengan kelahiran Undang-Undang Dasar 1945 yang disahkan oleh Panitia Persiapan Kemerdekaan Indonesia (PPKI) pada tanggal 18 Agustus 1945.

Setelah Sumpah Pemuda merumuskan sesuatu yang sifatnya tangible, yaitu mengenai tumpah darah, kebangsaan, dan menunjung bahasa persatuan, maka Pancasila adalah konsekuensi penting dari pergulatan para pendiribangsa ini. Pada, kenyataanya, sequence ini amat penting bagi bangsa dan negeri Indonesia yang keseluruhannya menjadi pribumi (native), bahkan bagi mereka yang menjadi imigran semenjak masa lampau.10 Beberapa bangsa hidup dengan warna imigran yang kuat, dan beberapa yang lain kesulitan memilih bahasa persatuan. Sequence ini penting juga dengan mempertimbangkan bahwa bangsa Indonesia adalah bangsa yang amat plu- ral, yang mungkin menjadi satu-satunya bangsa dengan tingkat keragaman yang begitu kaya dan seringkali ekstrem.

Sebagai bangsa multikultural, Negara Indonesia berdasarkan Pancasila ada- lah negara yang mengatasi paham golongan dan perseorangan. Dalam hal ini Bung Karno mengatakan dalam pidatonya:

"Sebagai tadi telah saya katakan, kita mendirikan Negara Indonesia, yang kita semua harus mendukungnya. Semua buat semua! Bukan Kristen buat Indonesia, bukan golongan Islam buat Indonesia, bukan Hadikoe- soemo buat Indonesia, bukan Van Eck buat Indonesia, bukan Nitisemito yang kaya buat Indonesia, tetapi Indonesia buat Indonesia-semua buat semua! 
Konfrontasi: Jurnal Kultur, Ekonomi dan Perubahan Sosial, 1 (1) Januari 2014, 50-59

P-ISSN: 1410-881X (Print)

\section{Yudi Latif, Pasang-Surut Komitmen Kebangsaan}

\section{DOI: -}

http://www.konfrontasi.net/index.php/konfrontasi2

Jikalau saya peras yang lima menjadi tiga, dan yang tiga menjadi satu, maka dapatlah saya satu perkataan Indonesia yang tulen, yaitu per- kataan 'Gotong-royong'. Negara Indonesia yang kita dirikan haruslah Negara gotong-royong!.”

Dalam kerangka falsafah gotong royong itu, misi nasionalisme progresif da- lam Indonesia merdeka telah diantisipasi dalam kandungan nilai dari ma- sing-masing dan keseluruhan sila Pancasila.

Dalam mengantisipasi kemungkinan menguatnya fundamentalisme agama, sila pertama menekankan prinsip ketuhanan yang berkebudayaan dan ber- keadaban. Seperti dinyatakan Bung Karno, "Hendaknya negara Indonesia ia- lah negara yang tiap-tiap orangnya dapat menyembah Tuhannya dengan ca- ra yang leluasa. Segenap rakyat hendaknya ber-Tuhan secara kebudayaan, yakni dengan tiadanya 'egoisme-agama'...Ketuhanan yang berbudi pekerti yang luhur, Ketuhanan yang hormat-menghormati satu sama lain."

Dalam mengantisipasi dampak-dampak destruktif dari globalisasi dan lo- kalisasi, dalam bentuk homogenisasi dan partikularisasi identitas, prinsip "sosio-nasionalisme" yang tertuang dalam sila kedua dan ketiga Pancasila telah memberikan jawaban yang jitu.

Dalam prinsip "sosio-nasionalisme", kebangsaan Indonesia adalah kebangsaan yang mengatasi paham perseorangan dan golongan, berdiri atas prinsip semua untuk semua. Saat yang sama, kebangsaan Indonesia juga kebang- saan yang berperikemanusiaan, yang mengarah pada persaudaraan, keadil- an dan keadaban dunia. Dikatakan Bung Karno, "Internasionalisme tidak dapat hidup subur, kalau tidak berakar di dalam buminya nasionalisme. Nasionalisme tidak dapat hidup subur, kalau tidak hidup dalam taman- sarinya internasionalisme".

Dalam mengantisipasi tirani dan ketidakadilan dalam politik dan ekonomi, prinsip "sosiodemokrasi" yang tertuang dalam sila keempat dan kelima Pancasila, memberi solusi yang andal. Menurut prinsip ini, demokrasi poli- tik harus bersejalan dengan demokrasi ekonomi. Pada ranah politik, demo- krasi yang dikembangkan adalah demokrasi permusyawaratan (deliberative democracy) yang bersifat imparsial, dengan melibatkan dan mempertim- bangan pendapat semua pihak secara inklusif. Pada ranah ekonomi, negara harus aktif mengupayakan keadilan sosial, dalam rangka mengatasi dan mengimbangi ketidaksetaraan yang yang terjadi di pasar, dengan jalan men- jaga iklim kompetisi yang sehat, membela yang lemah, serta berinvestasi da- lam public goods yang menyangkut hajat hidup orang banyak.

\section{Kesimpulan}

Demikianlah, para pendiri bangsa ini telah mewariskan kepada kita suatu falsafah berbangsa dan bernegara yang begitu visioner dan tahan banting (durable). Sayang sekali, keluasan daya jangkau dan daya jawab Pancasila itu belum banyak dikembangkan dan diamalkan secara jujur dan konsekuen dalam kehidupan berbangsa dan bernegara.

Seperti dikatakan almarhum Nurcholish Madjid, "Disebabkan oleh faktor kemudaan yang juga berarti kekurangmatangan kita semua sebagai bangsa baru, ide-ide terbaik para pendiri negara itu, dalam pelaksanannya sering berhadapan dengan apa yang dikatakan Bung Hatta sebagai jiwa-jiwa kerdil sebagian pemimpin kita."

Semoga peringatan 84 Tahun Sumpah Pemuda memberi momentum bagi penguatan komitmen kebangsaan dengan cara mengaktualisasikan nilai-ni- lai Pancasila.***

\section{Bibliografi}

Bagus, D. S. (1997). Pendidikan Politik bagi Generasi Muda dalam Upaya Memantapkan Budaya Politik. [ di akses 14 Des 2012].

Dugis, V. (2012). Peranan Nasionalisme dan Apa Pentingnya, disampaikan pada mata kuliah 


\section{Yudi Latif, Pasang-Surut Komitmen Kebangsaan}

\section{DOI: -}

http://www.konfrontasi.net/index.php/konfrontasi2

pengantar ilmu Hubungan Internasional. Departemen Hubungan Internasional. Universitas Airlangga, 22 Oktober 2012.

Kohn, H. (1965). Nationalism: Its Meaning and History, Princeton: D. Van Nostrand Company, 1965.

Kartodirdjo, S. (2003). Multidimensi Pembangunan Bangsa: Etos Nasionalisme dan Negara Kesatuan. Yogyakarta: Kanisius. Sejarah Nasionalisme dan Perspektif Islam", http://robbani.wordpress.co,/2007/08/01/4/. [ di akses 14 Des 2012].

Patrick, J. J. \& Thomas S. V. (2001). "Components of Education for Democratic Citizenship in the Preparation of Sosial Studies Teachers", dalam John J. Patrick dan Robert S. Leming (eds.), Principles and Pratices of Democracy in the Education of Social Studie Teacher: Civic Learning in Teacher Education, Volume 1, Bloomington, IN: ERIC Clearinghouse for Social Studies/Social Science Education, pp.39-33.

Tylor, E. B. (1974). Primitive Culture: researches into the development of mythodology, philosophy, religion, art, and custom. New York: Gordon Press. First published n 1871.

Wardaya, B. (2002). "Nasionalisme Universal: Menjawab Ajakan "PascaNasionalis"nya Romo Mangun”, dalam Jurnal Iman, Ilmu, Budaya. vol. 3. Sept. 2002. Jakarta: Yayasan Bhumiksara.

Yan, W. L. \& Murray, P. (2002). Nationalistic Education as the Focus for Civicand Citizenship Education: The Case of Hong Kong in Asia Pacific Education Review 2002, Vol. 3, No. 2, 197-209. 